\title{
RECENT ADVANCES IN ROLE OF PROPOLIS AS NATURAL ADDITIVE IN POULTRY NUTRITION
}

\author{
Sohail H. Khan \\ Poultry Research Institute, Murree Road, Shamsabad, Rawalpindi, Pakistan \\ corresponding author: sohailhassan64@gmail.com \\ Received: 6 June 2017; accepted: 8 October 2017
}

A bstract

Propolis is a natural resinous mixture produced by honey bees from substances collected from parts of plants, buds and exudates. Due to its waxy nature and mechanical properties, bees use propolis in the construction and repair of their hives for sealing openings and cracks and smoothing out the internal walls and as a protective barrier against external invaders and weathering threats. Bees gather propolis from different plants, in the temperate climate zone mainly from poplar. About 300 compounds such as polyphenols, phenolic aldehydes, sequiterpene quinines, coumarins, amino acids, steroids and inorganic compounds have been identified in propolis samples. Several scientific studies have been focused on the biological activities of propolis and its functions as a health supplement in humans. It could have akin function in poultry. This review is focused on the current findings relating to chemical composition, as an antioxidant, on performance, immunity, intestinal flora and haematological parameter in domesticated poultry species (broiler chickens, laying hens, quail and duck).

Keywords: haematological parameter of chicken, immunostimulation, nutrition, poultry, propolis

\section{INTRODUCTION}

The use of antibiotics as growth promoters for poultry production has been banned in many countries, which in turn caused their prohibition as protective agents against the emergence of infectious diseases and consequently increase in the economic losses for the poultry industry (Peric, Zikie, \& Lukie, 2009). Therefore, many researchers have attempted to find natural feed additives such as propolis to be used in poultry diets to reduce the expected harmful effects (Hegazi, Abdou, \& Allah, 2012; Abdel-Kareem \& El-Sheikh, 2015).

Propolis (bee glue) is a dark resinous material that honey bees (Apis mellifera L.) collect from tree buds and the exudates of plants and then chew and digest through oral enzymes (Seven, Aksu, \& Tatli, 2010). Bees are known to use propolis to overcome the inner walls of the hive and mix it with wax when building combs to protect the colony and larvae from pathogenic microorganisms (Simone-Finstrom \& Spivak, 2010) as well as the entrance against intruders (Miguel \& Antunes, 2011). Etymologically, the Greek word propolis means pro, for or in defense, and polis, the city, that is "defense of the hive". The microscopic structure of propolis is incredibly similar regardless of its origin (Açikgöz, Yücel, \& Altan, 2005). Generally, ethanol is the best solvent for propolis preparation, and other solvents such as ethyl ether, water, methanol, acetone, dichloromethane and chloroform may be used for extraction and identification of propolis compounds (Szliszka et al., 2013).

Although its composition slightly varies between regions and among seasons as a result of flora variation, propolis is generally composed of $50 \%$ resin and balsams, 30\% wax, 10\% essential and aromatic oils, 5\% pollen grains and other substances (Gómez-Caravaca et al., 2006). Propolis has been reported to be collected from resins of poplars, conifers, birch, pine, alder, willow, palm, Baccharis dracunculifolia, and Dalbergia ecastaphyllum (Kosalec et al., 2004). The ethanolic extract of propolis has been reported to possess such biological properties as antibacterial (Silici \& Kutluca, 2005), antiviral (Vynograd, Vynograd, \& Sosnowski, 2000), antiinflammatory, analgesic and tissue regenera- 
tive (De Castro, 2001), antioxidant (Banskota et al., 2000), and cytostatic and hepatoprotective (Banskota et al., 2000). They are attributed to its chemical composition, which consists of polyphenols, flavonoids, phenolic acids, aromatic aldehydes, esters, amino acids, minerals and vitamins (Schnitzler et al., 2010). The antibioticlike properties of propolis have been demonstrated by Scheller et al. (1999) and Seven \& Seven (2008). Pavilonis et al. (2008) reported that propolis preparations demonstrated in vitro anti-microbial activity mainly against Grampositive (Staphylococci and Strepthococci spp.), Gram-negative bacteria ( $E$. coli, K. pneumoniae, $P$. vulgaris and $P$. aeruginosa), Helicobacter pylori, protozoa (T. cruzi), fungi (Candida albicans) and viruses (HIV, Herpes viruses or influenza viruses).

Recent studies have suggested an increase in the production performance in poultry fed diets with propolis (Shalmany \& Shivazad, 2006; Seven, Aksu, \& Tatli, 2010; Tekeli, Kutlu, \& Çelik, 2011; Zafarnejad, Nazar, \& Mostafa, 2017). These advantages could be related to effect of propolis on gastrointestinal microbiota, which increase the levels of beneficial bacteria and decrease the pathogenic types (Kacaniova et al., 2012). This modulation of microbiota could promote intestinal health, given that the beneficial bacteria would nourish and protect the poultry against pathogens via competitive exclusion of various mechanisms (Lu et al., 2003).

This review highlights published data from works that focus on propolis and its composition, antioxidant property, effect on broiler and layer performance, as an immunostimulating agent, effect on intestinal microflora and haematological parameters. The potential of this natural compound needed to be determined for the development of a new feed additive in the poultry diet.

\section{Composition and properties of propolis}

Propolis is a hive product containing mainly beeswax and plant-derived substances such as resin and volatile compounds. Its chemical composition as well as color and aroma change

Table 1

Most important propolis types, geographical origin and major constituents

\begin{tabular}{|c|c|c|c|}
\hline Propolis type & Origin & Major components & References \\
\hline Poplar (P. nigra L.) & $\begin{array}{l}\text { Europe, North } \\
\text { America and } \\
\text { nontropic regions of } \\
\text { Asia }\end{array}$ & $\begin{array}{c}\text { Pinocembrin, pinobanksin, } \\
\text { chrysin, galangin, caffeic acid, } \\
\text { ferulic acid, cinnamic acid, and } \\
\text { their esters }\end{array}$ & $\begin{array}{l}\text { Ahn et al. (2004); } \\
\text { Chen et al. (2004); } \\
\text { Huang et al. (2007) }\end{array}$ \\
\hline Red propolis & $\begin{array}{c}\text { Cuba, Mexico, Brazil, } \\
\text { Venezuela }\end{array}$ & $\begin{array}{l}\text { Polyisoprenylated benzo- } \\
\text { phenones, Formononetin, } \\
\text { isoliquiritigenin, liquiritigenin, } \\
\text { medicarpin, and biochanin A }\end{array}$ & $\begin{array}{l}\text { Matsui et al. (2004); } \\
\text { Salatino et al. (2005); } \\
\text { Trusheva et al. } \\
\text { (2006) }\end{array}$ \\
\hline Green propolis & Brazil & $\begin{array}{l}\text { Prenylated phenylpropanoids, } \\
\text { phenolic acids, prenylated } \\
\text { p-coumaric acids, aceto- } \\
\text { phenones, diterpenic acids, } \\
\text { caffeoylquinic acids, kaemp- } \\
\text { feride, isosakuranetin, and } \\
\text { kaempferol }\end{array}$ & $\begin{array}{l}\text { Park et al. (2002); } \\
\text { da Silva Frozza et al. } \\
\text { (2013) }\end{array}$ \\
\hline $\begin{array}{l}\text { Mediterranean } \\
\text { propolis }\end{array}$ & $\begin{array}{l}\text { Greece, Malta, Crete, } \\
\text { Southern Italy }\end{array}$ & Diterpenes & $\begin{array}{l}\text { Popova et al. (2010); } \\
\text { Popova et al. (2012) }\end{array}$ \\
\hline Pacific & Taiwan, Japan & C-Prenyl-flavanones & Matsui et al. (2004) \\
\hline
\end{tabular}


according to the geographical zones (Tab. 1). The color varies from yellowish-green to red to dark brown depending on its source and age (Wagh, 2013). Its characteristic smell is due to the volatile oils it contains. Propolis varies in structure and consistency according to the temperature. It is hard and brittle at $0-15^{\circ} \mathrm{C}$, soft and malleable at around $30^{\circ} \mathrm{C}$, sticky between 30 to $60^{\circ} \mathrm{C}$ and liquefies at temperatures higher than $70^{\circ} \mathrm{C}$.

The biological properties of propolis are recognized as belonging a variety of major chemical constituents including phenolic acids, phenolic acid esters, flavonoids and terpenoids such as CAPE, artepillin C, caffeic acid, chrysin, and galangin quercetin, apigenin, kaempferol, pinobanksin 5-methyl ether, pinobanksin, pinocembrin, pinobanksin 3-acetate (Huang et al., 2014). The compounds identified in propolis resin originate from plant exudate collected by bees, secreted substances from bee metabolism, and materials which are introduced during propolis elaboration (Eroglu et al., 2016). Up to 2012 over 500 compounds from many countries have been identified in propolis and they belong to flavonoids, phenylpropanoids, terpenoids, stilbenes, lignans, coumarins and their prenylated derivatives (Huang et al., 2014). However, other common chemical components such as alkaloids, iridoids have not been reported in propolis, probably because of the plant sources.

The constituents of the Egyptian propolis are phenolic acid esters (72.7\%); phenolic acids (1.1\%); aliphatic acids (2.4\%); dihydrochalcones (6.5\%); chalcones (1.7\%); flavanones (1.9\%); flavones (4.6\%) and tetrahydrofuran derivatives (0.7 \%; Abd El-Hady \& Hegazi, 1994). Ozkok, Iscan \& llici (2013) reported that Turkish propolis contained $37.83 \%$ flavonoids (such as pinocembrin, chrysin and galangin); $18.54 \%$ organic acids and fatty acids (including 9-octadecanoic acid and n-hexadecanoic acid, coumaric acid, octadecanoic acid, cinnamic acid and derivatives); $35.8 \%$ aromatic acids and their esters, alcohols, aldehydes, ketones, terpenes and kinones; $4.89 \%$ various hydrocarbons and $2.94 \%$ other undefined components.

Propolis is rich in vitamins (i.e. $\mathrm{B}_{1^{\prime}}, \mathrm{B}_{2^{\prime}} \mathrm{B}_{6^{\prime}} \mathrm{C}$ and
E), mineral elements (i.e. $\mathrm{Ca}, \mathrm{Cu}, \mathrm{I}, \mathrm{K}, \mathrm{Mg}, \mathrm{Na}$, $\mathrm{Zn}, \mathrm{Mn}$ and $\mathrm{Fe}$ ), and enzymes (succinic dehydrogenase, adenosine triphosphatase, glucose6-phosphatase, acid phosphatase, $\alpha$-amylase, $\beta$-amylase, $\alpha$-lactamase, $\beta$-lactamase, maltase, esterase, and transhydrogenase) (Lotfy, 2006; Kurek-Górecka et al., 2014), in addition to a number of fatty acids, amino acids, terpenes, flavonoids and cinnamic acid derivatives (Wagh, 2013). The concentration of vitamins in North American propolis was reported as vitamin $A$ (6.1 IU/g of fresh matter and $8.1 \mathrm{lU} / \mathrm{g}$ of DM), vitamin $B_{1}(4.5 \mu$ g of fresh matter and $6.5 \mu$ of DM), $B_{2}$ (20 20 g of fresh matter and $28 \mu \mathrm{g}$ of DM) and vitamin $B_{6}(5 \mu \mathrm{g} / \mathrm{g}$ of fresh matterMoreira, 1986). This study also reported that the same propolis contained Cu (26.5 mg/kg), $M n(40 \mathrm{mg} / \mathrm{kg})$ and the ash residue contained Fe, Ca, Al, V, Sr and Si (Moreira, 1986). Trace elements ( $\mathrm{Al}, \mathrm{B}, \mathrm{Ba}, \mathrm{Cr}, \mathrm{Fe}, \mathrm{Mn}, \mathrm{Ni}, \mathrm{Sr}$ and $\mathrm{Zn}$ ) and toxic elements ( $\mathrm{As}, \mathrm{Cd}, \mathrm{Hg}$ and $\mathrm{Pb}$ ) were discovered through atomic emission/absorption spectrometry in propolis samples collected from different Croatian regions (Cvek et al., 2008). Some minerals such as $\mathrm{Br}, \mathrm{Co}, \mathrm{Cr}, \mathrm{Fe}, \mathrm{Rb}, \mathrm{Sb}, \mathrm{Sm}$ and $\mathrm{Zn}$ were identified in different Argentinean propolis through neutron activation analysis (Cantarelli et al., 2011). These studies show that the trace element profiles can be useful for propolis identification according to their location. Polysaccharides e.g., starch and di- and monosaccharaides glucose, fructose, ribose, rhamnose, talose, gulose, and saccharose аге commonly present in propolis (Kurek-Górecka et al., 2014). It may be concluded from literature that the chemical characteristics of propolis are linked to the diversity of geographical location, plant sources and bee species.

\section{Antioxidant capacity}

Antioxidants are agents which scavenge reactive oxygen species (ROS), prevent their formation and repair the damage they cause (Nimse \& Pal, 2015). Their effectiveness is due to their capability to donate their own electrons to free radicals, which then no longer attack cells and the chain reaction of oxidation is broken (Seven et al., 2012b). Recently, there has been a 
growing interest in the search for natural antioxidants to be used as substitutes for synthetic antioxidants, which has been restricted (restricted due to laws) because many of them have carcinogenic potential (Manal et al., 2015). Propolis could be this aspirant alternative for providing powerful antioxidant protection for the body. The antioxidant activities/ properties of propolis from such various geographic origins as Argentina, Australia, Brazil, China, and United States were confirmed in vitro by the presence of a strong defense against oxidative stress (Kumazawa, Hamasaka, \& Nakayama, 2004).

There is a correlation between the high content of total flavonoids and the anti free-radical activity in propolis (Da Silva et al., 2006). The flavonoids were suggested to play an important role in the antioxidant activity of Brazilian propolis extracts but other compounds could be involved. Another compound in the propolis structure, caffeic acid phenethyl ester, blocks the production of ROS (Hosnuter et al., 2004). The Chinese propolis was found to have the most antioxidative and the main component responsible for this property was identified as benzyl caffeate (Yamauchi et al., 1992). Several investigations on propolis in Eastern Europe and South America showed that flavonoids concentrated in propolis were powerful antioxidants and scavenged free radicals (Basnet, Matsuno, \& Neidlein, 1997; Banskota et al., 2000). Flavonoids and various phenolics in propolis have appeared to scavenge free radicals and thereby protect lipids and other compounds from being oxidized or destroyed during oxidative damage (Seven et al., 2009). Plus, flavonoids inhibit lipid peroxidation, platelet aggregation, capillary permeability and fragility (Havsteen, 2002). Furthermore, the flavonoid mechanisms as antioxidant action include the suppression of ROS formation either by inhibiting enzymes or by chelating trace elements involved in free radical generation, scavenging ROS and up-regulation or protection of antioxidant defenses (Mishra, Kumar, \& Pandey, 2013). The flavonoid occurrence, position, structure and total number of sugar moieties (flavonoids glycosides) play an important role in antioxidant activity (Kumar \& Pandey, 2013). Abou-Zeid et al. (2015) fed broilers diets with different levels of propolis $(0,125,250$ and $500 \mathrm{mg} / \mathrm{kg})$ and reported that in their blood the malondialdehyde (MDA) level decreased $(P \leq 0.01)$ and the antioxidant system as superoxide dismutase activity, catalase and glutathione peroxidase levels increased $(P \leq 0.001)$. Such an increase of antioxidant enzymes may be considered as a protective mechanism against induced free radical production and lipid peroxidation.

Hormonal and metabolic changes are also implicated in the response to prolonged or chronic exposure to heat stress. Seven et al. (2009) suggested that ether extract propolis at the supplemented dose of $3.0 \mathrm{mg} / \mathrm{kg}$ diet prevented oxidative stress in broilers exposed to heat stress. Recently, Mahmoud, AbdelRahman, \& Farghali (2015) recommended a $500 \mathrm{mg} / \mathrm{kg}$ diet dose of Chinese ether extract propolis to alleviate the hormonal and metabolic drawbacks of heat stress indicating through the lowest corticosteron level and maximum total antioxidant and MDA capacity in broilers. Similarly, feeding laying Japanese quails diets supplemented with two levels of propolis $(0.25$ and $0.50 \mathrm{~g} / \mathrm{kg}$ diet) during summer season resulted in decreased $(P \leq 0.05)$ serum MDA but increased $(P \leq 0.05)$ serum total antioxidant capacity and serum glutathione peroxidase as compared to the control group (Zeweil et al., 2016). This may refer to the strong antioxidant activity of propolis; due to the present phenols compound. Also, propolis prevents lipid oxidation because it contains chyrisin as one of the propolis compounds which having hepatoprotective and antioxidant activities (Sathiavelu et al., 2009) and also consist benzoic acid derivative exhibits antioxidant effects using inhibition assays of luminal luminescence, 2, 2-diphenyl-1picrylhydazyl and lipoperoxidation, particularly caffeic acid, caffeoylquinic acid and cinamic acid are effective $\mathrm{O}_{2}$ - scavenging activity (Nakajima et al., 2007).

High stocking density in poultry may enhance oxidative destruction and cause MDA generation. Additionally, tissues are detrimentally affected by oxidative stress which could be prevented 
with propolis supplementation in poultry diets. Arslan \& Seven (2017) found that serum MDA levels of the high stocking quail group were significantly higher $(6.84 \mathrm{nM} / \mathrm{mL})$ than those groups of supplementation of $0.5 \mathrm{~g}(4.33 \mathrm{nM} / \mathrm{mL}), 1.0 \mathrm{~g}$ (4.08 nM/mL) and $1.5 \mathrm{~g}(4.56 \mathrm{nM} / \mathrm{mL})$ propolis/kg. They explained that the antioxidative property of propolis was based on its rich flavonoid, phenolic acid and terpenoid contents.

Antioxidant stability is important for meat storage and durability, because poultry meat and mainly poultry fat contain higher amounts of polyunsaturated fatty acids in comparison with fat of other slaughtered animals (MartinezTome et al., 2001). Haščik et al. (2014) tested the influence of propolis extract applied to feed mixtures of broiler chickens on the oxidative stability of breast and thigh muscles stored at $-18{ }^{\circ} \mathrm{C}$ for six months. During the storage, the highest MDA values were found in the control group and the best results (the lowest MDA value) were found in the group with applied propolis extract at a dose of $800 \mathrm{mg} / \mathrm{kg}$. The application of propolis extract in broiler chickens nutrition significantly influences $(P \leq 0.05)$ a decrease oxidative processes in breast and thigh muscles during the whole storage period. Similar results were obtained in another study which used propolis extract at a dose of $450 \mathrm{mg} / \mathrm{kg}$ in the broiler diet (Bobko et al., 2015). It may be concluded from above studies that propolis alleviates the negative effects of oxidative stress in poultry.

\section{Immunostimulating agent}

Propolis stimulates the body's immune system and thus improves the growth performance, health status of broilers and laying hens (by reducing mortality rates and improving feed conversion), carcass value and meat quality characteristics (Zeng et al., 2004; Roodsari et al., 2004; Denli et al., 2005). It has been shown to stimulate lymphocyte proliferation and antibody production after immunization. Depending on the dose and time of administration, propolis components may enhance $T$ Iymphocyte conversion. As demonstrated by Chen, Qiu \& Lin (1999), propolis extracts boost immune system development and stimulate the activity of $\mathrm{T}$ and B lymphocytes in broiler chickens. The bursa and spleen are sites of $B$ cell and $T$ cell differentiation, respectively. Zafarnejad, Nazar, \& Mostafa (2017) reported that the inclusion of $0.9 \mathrm{~g} / \mathrm{kg}$ propolis in the broiler diet significantly increased the relative weight of bursa $(0.202 \mathrm{mg} / \mathrm{kg})$ and spleen $(0.140 \mathrm{mg} / \mathrm{kg})$ as compared to the control group (0.163 and $0.131 \mathrm{mg} / \mathrm{kg}$, respectively).

The serum antibody titer is a valid indicator of humoral immunity in poultry and plays an important role in the host's defense against infections. Serum IgG and IgM concentrations in the broilers receiving $0.7,0.8$ and $0.9 \mathrm{~g} / \mathrm{kg}$ of propolis were significantly higher than those in control birds, suggesting that high levels of propolis modulate humoral immunity in broilers (Zafarnejad, Nazar, \& Mostafa, 2017). Similarly, the addition of $3.0 \mathrm{~g}$ propolis/kg in the diet of broiler chickens and laying hens resulted in significant increases in the serum lgG and IgMlevels and significant decreases in the peripheral blood T-lymphocytes compared with those of the controls (Çetin et al., 2010; Shihab \& Ali, 2012). The increased levels of $\mathrm{IgG}$ in birds treated with propolis may be related to the stimulation of $B$ lymphocytes through increased macrophage activity and concentrations of such cytokines as interleukin-1, interleukin-2, and interleukin-4 (Park et al., 2004). These cytokines further stimulate B Iymphocytes to become plasma cells, producing immunoglobulins (Dimov et al., 1991). This could be attributed to the benzene and flavonoids constituents of propolis which cause a greater immune response because macrophage phagocytic activity increases and more cytokines are produced, and this turn stimulates the proliferation of other immune cells (Taheri, Rahmani, \& Pourreza, 2005). For birds' physiological defenses, macrophages phagocytose, chemotax, mediate inflammatory processes and secrete substances involved in immune processes (Orsi et al., 2000).

Propolis supplementation increased the antibody response to the Newcastle disease virus (NDV), infectious bursal disease and avian influenza (Taheri, Rahmani, \& Pourreza, 2005; Ziaran, Rahmani, \& Pourreza, 2005), but did not 
affect infectious bronchitis (Taheri, Rahmani, \& Pourreza, 2005). Similarly, Freitas et al. (2011) stated that supplementation of propolis in laying hen feed $(50 \mathrm{mg} / \mathrm{kg})$ increased the production of IgG specifically for sheep red blood cells and natural antibodies; indicating that propolis could be used to increase antigen-specific antibody responses to vaccines. Recently, Babaei et al. (2016) reported that propolis $(1.0 \mathrm{~g} / \mathrm{kg})$ in a quail diet caused an increase in the ND titer when compared with control and antibiotic (virginiamycin) groups.

Hegazi, El-Miniawy, \& El-Miniawy (1995) studied how some bee products affected the immune response of virulent NDV-infected chicken. They reported a reduced mortality rate in groups infected with virulent NDV which were subsequently treated either with propolis or honey. The results showed that propolis as an antiviral agent out performed honey. The propolis and honey treatment of NDV- infected chicken groups induced increased antibody titres and phagocytic percentage. A possible mechanism involved in the increased levels of antibodies produced after antigenic stimulation in propolis-treated birds is probably related to increase expression of IL-2 and interferon- $\gamma$ because these cytokines stimulate antibody production in chickens (Wang et al., 2006). Such increased antibody production suggests that propolis has an immunostimulatory effect on chickens and could be used to increase antigen-specific antibody responses to vaccines.

Ziaran, Rahmani, \& Pourreza (2005) reported that both humoral and cellular immune responses were modulated by different levels of oil extract of propolis in the broilers diet and suggested that a low level ( 40 and $70 \mathrm{mg} / \mathrm{kg}$ ) of dietary propolis developed the immune response while chickens fed a highly enriched propolis diet showed a lower immune response. Similarly, Taheri, Rahmani, \& Pourreza (2005) observed a relatively negative effect of a higher concentration of propolis on the humoral immunity of broilers and concluded that the immune system may respond to propolis at a crucial dosage $(100 \mathrm{mg} / \mathrm{kg})$. The results regarding an antibody against Newcastle and bursal virus on days
21 and 42 revealed that the antibody concentration increased with the propolis level up to $100 \mathrm{mg} / \mathrm{kg}$ but with higher levels of propolis the antibody concentration declined $(P \leq 0.05)$. However, Eyng, Murakami, \& Pedroso (2013) found that crude propolis at $100 \mathrm{mg} / \mathrm{kg}$ in the broilers' feed was an effective immunostimulating agent for cell-mediated responses during the starter phase. Galal et al. (2008) reported that the in vivo cell-mediated immune response as measured by phytohemagglutinin- P stimulation (wattle) revealed that the laying hens fed a diet with an added 50, 100 and $150 \mathrm{mg}$ propolis/ $\mathrm{kg}$ had a significant hyper-responder compared to the control group. Concerning white blood cell differentiation, propolis supplementation significantly decreased heterophils count and increased lymphocytes count when compared with the control group.

Immunomodulatory activity can also be evaluated through the measurement of nitric oxide production in macrophages, which is a microbicide compost associated with macrophage activity (Bogdan, 2001; Sforcin, 2007). Nitric oxide production in broilers given a $100 \mathrm{mg} / \mathrm{kg}$ propolis supplement was higher compared with other propolis doses, which may be associated with the higher phagocytic activity observed (Eyng, Murakami, \& Pedroso, 2013). Recently, Eyng et al. (2015) reported that the inclusion of 1 to $4 \%$ of propolis extraction residue in broiler diets from 1 to 21 days of age was not able to improve the immune parameters despite the modest changes in the relative weight in thymus, blood monocyte percentage and nitric oxide concentration. Inconsistency among results of different studies may be related to the type and dosage of propolis and its constituents in the diets, duration of feeding with experimental diets, study population (i.e., in age, weight, or breed) and animal species.

\section{Effect of propolis on intestinal microflora}

The intestinal microflora provides a natural barrier against harmful bacteria that enter the intestine. They enhance the immune system by inhibiting the growth of exogenous and pathogenic bacteria, and produce bacteriocins 
or other substances (Lan et al., 2005). Propolis exhibits bacteriostatic activity against different bacterial genera and can be bactericidal at high concentrations (Drago et al., 2000). Kačániová et al. (2012; 2013) reported that the highest count of faecal Enterococci (8.65cfu/g) was found in the chickens fed a diet containing 0.2 or $0.60 \mathrm{~g}$ propolis $/ \mathrm{kg}$. The highest count of Lactobacilli (8.83cfu/g) was detected in the chickens fed a diet containing $0.80 \mathrm{~g}$ propolis/kg while the highest count of Enterobacteriaceae genera was found in the control group (8.73cfu/g).

The in vitro antimicrobial activity of six species of bacteria isolated from the gastrointestinal tract of chickens was also tested. The ethanolic propolis extract in all concentrations $(0.15,0.45$, 0.60 or $0.80 \mathrm{~g} / \mathrm{kg}$ ) had the greatest antimicrobial affect on Citrobacter braakii. The supplementation of propolis $(0.10,0.25,0.50$ ог $0.75 \mathrm{~g} / \mathrm{kg}$ diet) significantly stimulated the numbers of Lactobacillus spp. and Bifidobacteria spp. in the broiler gut under both the recommended temperature (16 to $25^{\circ} \mathrm{C}$ ) and chronic heat stress conditions (Mahmoud, Abdel-Mohsein, \& Mahmoud, 2014; Abdel-Mohsein, Mahmoud, \& Mahmoud, 2014). On the contrary, dietary supplementation of propolis at $1.0 \mathrm{~g} / \mathrm{kg}$ diet (Tekeli et al., 2010) or 0.40 or $0.80 \mathrm{~g} / \mathrm{kg}$ diet (Kročko et al., 2012) in broilers was found not to influence the numbers of intestinal lactic acid bacteria. The supplementation of propolis has not been shown to affect caecal numbers of total coliforms, E. coli and Enterococcus spp. in chickens (Tekeli et al., 2010; Mahmoud, Abdel-Mohsein, \& Mahmoud, 2014).

\section{Haematological parameters}

Propolis appears to have a significant effect on the hematological parameters of poultry. Galal et al. (2008) reported that the hematocrit level significantly increased in laying hens receiving $0.15 \mathrm{~g} / \mathrm{kg}$ of propolis in their diet. Similarly, Çetin et al. (2010) documented a slight increase in haematocrit and haemoglobin values in laying hens receiving $3.0 \mathrm{~g} / \mathrm{kg}$ of propolis. In broiler chicken, packed cell volume and heterophil counts significantly increased at a dose of $2.0 \mathrm{~g}$ propolis/kg diet (Shaddel-Tili et al., 2016). AbdelRahman \& Mosaad (2013) found that ducks fed propolis diets had much higher haemoglobin con- centrations than the control, but the packed cell volume was not affected. These results suggest that propolis improved the digestive utilization of iron and reduced the regeneration efficiency of haemoglobin. Dietary propolis supplementation may help the prevention of anaemia in poultry. Red blood cell counts increased in broiler chickens fed propolis at 2.0 or $3.0 \mathrm{~g} / \mathrm{kg}$ diet (Shihab \& Ali, 2012), in laying hens at 3.0 $\mathrm{g} / \mathrm{kg}$ (Çetin et al., 2010) and in ducks at $2.0 \mathrm{~g} / \mathrm{kg}$ (Abdel-Rahman \& Mosaad, 2013). These results indicate that propolis may have a stimulatory effect on the synthesis and release of these cells from the bone marrow of various poultry species.

Abbas (2014) reported that total serum protein, albumin, and globulins levels decreased ( $p<0.05)$. However, glucose levels increased when chicks received the high propolis dose $(2.5 \mathrm{~g} / \mathrm{kg})$ compared to control group. There was no significant difference between control and propolis groups in hemoglobin concentration or packed cell volume.

Mahmoud, Abdel-Mohsein, \& Mahmoud (2014) showed that addition of a low dose of propolis $(0.25 \mathrm{~g} / \mathrm{kg})$ did not affect serum total protein and globulin values but instead increased with the addition of the highest dose $(0.75 \mathrm{~g} / \mathrm{kg})$. Moreover, serum total protein and globulin levels significantly increased in Sasso chickens fed with $2.0 \%$ propolis from 3 to 8 wk of age (Omar et al., 2004) and in laying hens fed 0.1or 0.15 g propolis/kg diet from wk 46 to 54 (Galal et al., 2008) under thermo-neutral temperatures. Abdel-Rahman \& Mosaad, (2013) indicated that adding propolis $(2.0 \mathrm{~g} / \mathrm{kg}$ ) to the diet of Muscovy ducks maintained at $33^{\circ} \mathrm{C}$ resulted in significantly higher amounts of serum total protein, albumin and total globulin. They also attributed the improved serum total protein and its fractions in the propolis-fed group to its stimulating effect on the liver exhibiting anabolic action favoring protein synthesis and its preserving effect on the body protein from degeneration.

Blood cholesterol and triglyceride levels were significantly reduced in propolis-fed laying hens (0.10 or $0.15 \mathrm{~g} / \mathrm{kg}$ diet; Galal et al., 2008), broiler chickens $(0.30$ to $0.90 \mathrm{~g} / \mathrm{kg}$ diet; Attia et al., 2014; Haščík et al., 2016; Zafarnejad, Nazar, \& 
Mostafa, 2017) and Japanese quail (0.25 or 0.50 $\mathrm{g} / \mathrm{kg}$ diet; Zeweil et al., 2016). The decrease in triglycerides and cholesterol may be attributed to propolis that either plays a major role as antioxidant material to increase glutathione enzyme activity, or contains such components as essential fatty acids which inhibit hepatic 3-hydroxy-3-methylglutaryl coenzyme A reductase activity which is a key regulatory enzyme in cholesterol synthesis (Matsui et al., 2004; Babińska et al., 2013).

\section{Broilers performance}

Many authors have suggested an increase in the growth performance in broilers fed with propolis (Shalmany \& Shivazad, 2006; Seven, Aksu, \& Tatli, 2010; Tekeli, Kutlu, \& Çelik, 2011). These effects could be related to the effect of propolis extract on gastrointestinal microbiota, which increases the levels of beneficial bacteria and decreases the pathogenic types (Kačánioá et al., 2012). This modulation of microbiota could promote intestinal health, given that the beneficial bacteria could provide nutrition and protection to the animals against pathogens via competitive exclusion through a variety of mechanisms (Lu et al. 2003).

Body weight (BW) has been shown to increase by $2.03 \%$ in broiler chickens fed with $0.1 \%$ propolis compared with the control group (Zhi-jiang et al., 2004). Similarly, with $2.5 \%$ propolis contributed to higher body weight gains (BWG) and higher feed efficiency, thus increasing production profitability by almost 10\% (Li and Zhang, 2002). In another experiment, a combination of flower pollen and propolis (2.5:1), used as a feed additive, increased the BW of chickens by nearly $10 \%$ in comparison with the control group (Zeng et al., 2004).

In different studies, various levels of propolis per kg broiler's diet like 0.05g (Kleczek et al., 2014), 0.25g (Roodsari et al., 2004), 0.5 \& $1.5 \mathrm{~g}$ (Abbas, 2014), 0.6 to $0.9 \mathrm{~g}$ (Zafarnejad, Nazar, \& Mostafa, 2017), 3.0g (Hosseini et al., 2016) and 5.0g (Seven \& Seven, 2008) greatly improved BW, BWG and feed conversion ratios (FCR). The dose response of propolis has been reported to greatly increase the BW and BWG of broiler chickens when feeding propolis at 0.05 , $0.10,0.15,0.20,0.25,0.5,1.5$ and $2.0 \mathrm{~g} / \mathrm{kg}$ diet (Shalmany \& Shivazad, 2006; Shaddel-Tili et al., 2016).

Similar results have been reported in other poultry species. Japanese quail (Coturnix japonica) had improved BW after supplementation with $1.0 \mathrm{~g}$ propolis/kg diet between 14 to 35 days of age (Denli et al., 2005). Likewise, Tayeb \& Sulaiman (2014) reported that water supplementation with $0.30 \mathrm{~g}$ propolis/L water increased $(P \leq 0.05)$ the live $B W$ of quail as compared to the control group. Abdel-Rahman \& Mosaad (2013) found that broiler ducks fed propolis at $2.0 \mathrm{~g} / \mathrm{kg}$ feed were heavier ( $\mathrm{P} \leq 0.01)$ in BW at 12 weeks than control ( 7.393 and 6.242 $\mathrm{kg}$, respectively). Similarly, the propolis-added group showed improved $(P \leq 0.01) F C R$ than the control group (3.48 and $4.36 \mathrm{~g}$ feed/g gain, respectively). Bonomi et al. (2002) reported that broiler duck BWG increased by 10.50 and $13.50 \%$ by supplementation with 0.02 or $0.04 \mathrm{~g}$ propolis/kg diet, respectively during day-old to 60 days of age. The improvement in feed intake (FI) and FCR was recognized to enhance flavour through the flavonoid content in propolis, and/ or due to components such as benzoic and 4-hidoxibenzoic acid, which may improve the digestibility of such nutrients as protein and ash (Seven, 2008; Seven, Aksu, \& Tatli, 2012a).

Conversely, in some other studies have reported that propolis supplementation of broiler diets at different doses of 0.04 to1.0 g/kg (Ziaran, Rahmani, \& Pourreza, 2005; Haščík et al., 2016) and quail diets at doses of $0.25,0.50,1.0$ and $5.0 \mathrm{~g} / \mathrm{kg}$ (Babaei et al., 2016; Zeweil et al., 2016) had no effect on BWG. Some researchers demonstrated that FCR improved when propolis was added to broiler chickens diets under heat stress conditions at doses of 0.20 or $0.25 \mathrm{~g} / \mathrm{kg}$ (Roodsari et al., 2004), 1.0 g/kg (Ziaran, Rahmani, \& Pourreza, 2005) and $5.0 \mathrm{~g} / \mathrm{kg}$ (Seven, 2008) and to quail diets at doses of $0.5,1.0$ and 1.5 $\mathrm{g} / \mathrm{kg}$ (Denli et al., 2005). This improvement may be due to the ability of propolis to progress nutrient digestibility and absorption which stimulate the activities of saccharase, amylase and phosphatase (Marieke et al., 2005). 
Some studies have recommended propolis supplementation as an alternative to antibiotics in broilers. Kleczek et al. (2014) reported that the growth performance of broilers fed a diet supplemented with $0.05 \mathrm{~g}$ propolis/kg diet was comparable to the growth performance of chickens fed a diet with antibiotic growth promoters. Seven \& Seven (2008) compared how the performance of heat stressed broilers were affected by propolis ( $5 \mathrm{~g} / \mathrm{kg}$ of diet) and by antibiotics. Data showed that higher $\mathrm{FI}$ in the propolis group compared to the heat stress group could be linked to the palatable characteristic of propolis diets. The heat stress group showed $8.33 \%$ mortality, but in antibiotic and propolis groups it decreased to $3.33 \%$ and $5 \%$, respectively. Propolis was explained to have stimulated the immune system which decreased the mortality rate. These results is attributed to the antimicrobial (antibacterial, antifungal, antiviral and antiprotozoal) properties of propolis which are of value as growth promoting agents since they prevent subclinical infections (Scheller et al., 1999). Moreover, propolis is known to contain protein, amino acids, vitamins, flavinoids and minerals, which are important nutrients in increasing the growth performance of poultry (Babaei et al., 2016).

Propolis supplementations have been shown to increase carcass weight, yield and dressing percentage in broiler chickens, quails and ducks (Bonomi et al., 2002; Seven et al., 2008; Hassan \& Abdulla, 2011; Zafarnejad, Nazar, \& Mostafa, 2017). The relative weight of the small intestine, proventriculus, gizzard, liver, heart, thighs, spleen, bursa, pancreas dorsal and chest parts, legs, neck, wings, abdominal fat and chilled percentage were not affected by propolis treatment in either broiler chickens or quail (Denli et al., 2005; Seven et al., 2008; Babińska et al., 2013; Mahmoud, Abdel-Rahman, \& Darwish, 2013). Only the relative weight of the crop was improved by the propolis supplementation and this influence may have been related to the increased $\mathrm{FI}$ that was observed at the same time (Zafarnejad, Nazar, \& Mostafa, 2017). However, Hassan \& Abdulla (2011) demonstrated that the proportional weight of the liver was significantly higher in broiler chickens fed $0.40 \mathrm{~g}$ propolis/kg diet than that of the control group and Tayeb \& Sulaiman (2014) reported that supplementation with $0.30 \mathrm{~g}$ propolis/L water increased $(P \leq 0.05)$ the carcass weight, thigh, back and wing of quail as compared to the control group. Contrary to the above studies, Hašč́k et al. (2016) reported that the supplementation of the diet with propolis extract (0.4 $\mathrm{g} / \mathrm{kg}$ ) had no effect on carcass yield of broiler chickens compared to the control.

A propolis-supplemented diet $(0.025 \%)$ fed to broiler chickens for the first two weeks of age affected neither their weight and length of tibial bones or their percentage shares of total BW nor the geometric parameters of the tibia and its biomechanical properties. Dry matter content and phosphorus concentrations of the chicken tibial bones were not affected but the concentration of calcium in bone ash was significantly reduced (Kleczek et al., 2012).

\section{Laying hens performance}

A limited number of research studies has been done on the supplementation of propolis in laying hen diets. Galal et al. (2008) reported that supplemental propolis at 0.10 and $0.15 \mathrm{~g} / \mathrm{kg}$ diet significantly improved $\mathrm{Fl}, \mathrm{FCR}$, egg production, egg weight and egg mass as compared to the control. Similarly, egg weight, Haugh unit, shell thickness and breaking strength also significantly increased after a feeding of 0.10 and $0.15 \mathrm{~g}$ propolis $/ \mathrm{kg}$ diet. They explained that increased $\mathrm{Fl}$ in the propolis groups may be due to the higher palatability of propolis diets due to a mixture of resin, wax, honey and vanillin content in propolis. Recently, Abdel-Kareem \& El-Sheikh (2015) observed that laying hens fed with diets containing 0.25 and 1.0 propolis/kg produced more and heavier eggs $(P<0.05)$ in comparison with the control group. The only external egg quality trait to be affected by the increased propolis level was eggshell weight which increased $(P \leq 0.05)$. Except for albumen and yolk percentages, the internal egg quality traits for treated hens improved $(P \leq 0.05)$ with the increasing propolis level as compared to those in the control. Contrary, Belloni et al. 
(2015) repor ted that FI decreased as the dietary propolis inclusion level increased (1.0 to 3.0\%) in the layer's diet. This reduction in $\mathrm{FI}$ may be due to the astringent flavor of propolis. These researchers found that the use of propolis in the hens' diet did not improve performance and worsened the eggs' quality. Similarly, Ozkok, Iscan, \& Ilici (2013) reported that propolis doses $(0.1,0.2$ or $0.4 \mathrm{~g} / \mathrm{kg}$ ) did not have any dietary effects on either such performance criteria as Fl, FCR, egg production, egg weight or such egg quality criteria as Haugh units and shell thickness. However, El-Neney \& Awadien (2014) reported that layers fed a diet supplemented with propolis $(0.1,0.2$ or $0.3 \mathrm{~g} / \mathrm{kg})$ had a significantly improved final BW, BWG, FCR, egg production, egg weight and egg mass per hen.

Seven (2008) reported that supplementation with vitamin $C$ and two different propolis doses (2.0 and $5.0 \mathrm{~g} / \mathrm{kg}$ diet) in laying hens exposed to heat stress greatly improved performance (increases of FCR and BWG), egg qualities, weight, shape index, yolk index, albumen index, Haugh units, shell thickness, egg shell weight) and nutrient digestibility. The positive effects of propolis on eggshell quality could be linked to an increase in calcium digestibility and absorption due to its acid derivatives such as benzoic, 4-hydroxy-benzoic acids (Seven, 2008; Seven, Tatli, \& Silici, 2011). On the contrary, Zeweil et al. (2016) reported that no significant difference was observed in egg laying rate, weight, number and mass of 15 -wk old laying quails due to the supplementing ascorbic acid $(0.25 \mathrm{~g} / \mathrm{kg}$ diet) or two levels of propolis ( 0.25 or $0.5 \mathrm{~g} / \mathrm{kg}$ diet) as compared with the control group. This difference may be due to different species and doses of propolis used in the above studies.

Different studies have indicated that the effects of propolis on poultry performance are affected by such multiple factors as type and dosage, active component levels, feeding duration, physiological factors (age, weight and breed) and species. However, the positive findings for propolis on the performance of poultry support its stated biological functions as an antioxidant, antibacterial, immunestimulant and growth promoter; and indicate the potential use of propolis as a natural feed additive. Further research on the best techniques for its application on poultry farms is required.

\section{REFERENCES}

Abbas, R.J. (2014). Effect of dietary supplementation with differing levels of propolis on productivity and blood parameters in broiler chicks. Basrah Journal of Veterinary Research, 13(2), 164-180. http://www. iasj.net/iasj?func=fulltext\&ald=98808

Abd El-Hady, F.K. \& Hegazi, A.C. (1994). Gas chromatography - mass spectrometry (GC/MS) study of the Egyptian propolis 1- aliphatic, phenolic acids and their esters. Egyptian Journal of Applied Sciences, 9, 749-760.

Abdel-Kareem, A.A.A. \& El-Sheikh, T.M. (2015). Impact of supplementing diets with propolis on productive performance, egg quality traits and some haematological variables of laying hens. Journal of Animal Physiology and Animal Nutrition, 107(3), 441-448. DOl: 10.1111/.jpn.12407

Abdel-Mohsein, H.S., Mahmoud, M.A.M. \& Mahmoud, U.T. (2014). Influence of propolis on intestinal microflora of Ross broilers exposed to hot environment. Advances in Animal and Veterinary Sciences, 2(4), 204-211. http://dx.doi.org/10.14737/journal. aavs/2014/2.4.204.211

Abdel-Rahman, M.A. \& Mosaad, G.M. (2013). Effect of propolis as additive on some behavioural patterns, performance and blood parameters in muscovy broiler ducks. Journal of Advanced Veterinary Research, 3, 64-68. http://www.advetresearch.com/ index.php/AVR/article/view/117/114

Abou-Zeid, A.E., El-Damarawy, S.Z., Mariey, Y.A. \& ElKasass, S.M. (2015). Effect of dietary propolis supplementation on performance and activity of antioxidant enzymes in broiler chickens. Egyptian Journal of Nutrition and Feeds, 18, 391- 400.

Açikgöz, Z., Yücel, B. \& Altan, O. (2005). The effects of propolis supplementation on broiler performance and feed digestibility. Archiv Fur Geflugelkunde, 69S, 


\section{7-122.}

Ahn, M.R., Kumazawa, S., Hamasak, T., Bang, K.S., Nakayama, T. (2004). Antioxidant activity and constituents of propolis collected in various areas of Korea. Journal of Agricultural and Food Chemistry, 52, 7286-7292. DOl: 10.1021/jf048726s

Arslan, A.S. \& Seven, P.T. (2017). The effects of propolis on serum malondialdehyde, fatty acids and some blood parameters in Japanese quail (Coturnix coturnix japonica) under high stocking density. Journal of Applied Animal Research, 45, 417-422. http:/l dx.doi.org/10.1080/09712119.2016.1206901

Attia, Y.A., Abdal-Hamid, A.E., Ibrahim, M.S., Al-Harthi, M.A., Bovera, F." Elnaggar, A.S. (2014). Productive performance, biochemical and hematological traits of broiler chickens supplemented with propolis, bee pollen, and mannan oligosaccharides continuously or intermittently. Livestock Science, 164, 87-95. https://doi.org/10.1016/j.livsci.2014.03.005

Babaei, S., Rahimi, S., Torshizi, M.A.K, Tahmasebi, G., Miran, S.N.K. (2016). Effects of propolis, royal jelly, honey and bee pollen on growth performance and immune system of Japanese quails. Veterinary Research Forum, 71), 13-20. http:// vrf.iranjournals.ir/article_19009_3cfe58f0e4c2d359a012f671e8656c23.pdf

Babińska, I., Kleczek, K., Makowski, W. \& Szarek, J. (2013). Effect of feed supplementation with propolis on liver and kidney morphology in broiler chickens. Pakistan Vet Journal, 33(1), 1-4. http://www.pvj.com. pk/pdf-files/33_1/01-04.pdf

Basnet, P., Matsuno, T. \& Neidlein, R. (1997). Potent free radical scavenging activity of propol isolated from Brazilian propolis. Zeitschrift für Naturforschung, 52C, 828-833. http://zfn.mpdl.mpg.de/ data/Reihe_C/52/ZNC-1997-52c-0828.pdf

Banskota, A.H., Tezuka, T., Adyana, I.K., Midorikawa, K., Matsushige, K., Message, D., ... Kadota, S. (2000). Cytotoxic, hepatoprotective and free radical scavenging effects of propolis from Brazil, Peru, the Netherlands and China. Journal of Ethnopharmacology,
72(1-2), 239-246. https://doi.org/10.1016/S0378$8741(00) 00252-x$

Belloni, M, Almeida, P.l.C.L., Nääs, I.A., Alves, M.C.F., Garcia, R.G., Caldara, F.R., Seno, L.O. (2015). Productive, qualitative, and physiological aspects of layer hens fed with propolis. Brazilian Journal of Poultry Science, 174), 467-472. http://www.redalyc.org/ pdf/1797/179743242009.pdf

Bobko, M., Kročko, M., Haščík, P. \& Bobková, A. (2015). Oxidative stability of chicken meat after propolis extract application in their diets. Potravinarstvo, 9, 48-52.

Bogdan, C. (2001). Nitric oxide and the immune response. Nature Immunology, New York, 2, 907-916.

Bonomi, A., Bonomi, B.M., Quarantelli, A., Sabbioni, A. Superchi, P. (2002). The use of propolis in duck feeding. Rivista di Scienza dell'Alimentazione, 37, 15-28.

Cantarelli, M.A., Caminia, J.M., Pettenati, E.M., Marchevsky, E.., Pellerano, R.G. (2011). Trace mineral content of Argentinean raw propolis by neutron activation analysis (NAA): Assessment of geographical provenance by chemometrics. LWT-Food Science and Technology, 44, 256-260.

Cetin, E., Silici, S., Cetin, N. \& Guclu, B.K. (2010). Effects of diets containing different concentrations of propolis on hematological and immunological variables in laying hens. Poultry Science, 89(8), 17031708. https://doi.org/10.3382/ps.2009-00546

Chen, S., Qiu, Z. \& Lin, W. (1999). The immunogenicity of ultrasonicated vaccine of chicken pathogenic E. Coli (078) against Colibacillosis. Journal of South China Agricultural University, 201), 37-40.

Chen, C.N., Weng, M.S., Wu, C.L. \& Lin, J.K. (2004). Comparison of radical scavenging activity, cytotoxic effects and apoptosis induction in human melanoma cells by Taiwanese propolis from different sources. Evidence-Based Complementary Alternative Medicine, 1:175-185. DOl: 10.1093/ecam/neh034

Cvek, J., Medid-Saric, M., Vitali, D., Vedrina-Dragojevik, 
I., Smit, Z., Tomic, S. (2008). The content of essential and toxic elements in Croatian propolis samples and their tinctures. Journal of Apicultural Research, 47, 35-45. http://dx.doi.org/10.1080/00218839.2008.1 1101421

Da Silva, J.F.M., Souza, M.C., Matta, S.R., Andrade, M.R., Vidal, F.V.N. (2006). Correlation analysis between phenolic levels of Brazilian propolis extracts and their antimicrobial and antioxidant activities. Food Chemistry, 99(3), 431-435. https://doi.org/10.1016/j. foodchem.2005.07.055

DaSilvaFrozza, C.O., Garcia, C.S.C., Gambato, G., de Souza, M.D.O., Salvador, M., Moura, S., Padilha, F.F., Seixa, F.K., Collares, T., Borsuk, S., Dellagostin, O.A., Henricues, J.A.P. \& Roesch-Ely, M. (2013). Chemical characterization, antioxidant and cytotoxic activities of Brazilian red propolis. Food and Chemistry Toxicology, 52,137-142. https://doi.org/10.1016/j. fct.2012.11.013

De Castro, S.L. (2001). Propolis: Biological and pharmacological activities. Therapeutic uses of this beeproduct. Annual Review of Biomedical Sciences, 3, 49-83. http://132.248.9.34/hevila/ARBSAnnualreviewofbiomedicalsciences/2001/vol3/2.pdf

Denli, M., Cankaya, S., Silici, S., Okan, F., Uluocak, A.N. (2005). Effect of dietary addition of Turkish propolis on the growth performance, carcass characteristics and serum variables of quail (Coturnix coturnix japonica). Asian-Australasian Journal of Animal Science, 18(6), 848-854. https://doi.org/10.5713/ ajas.2005.848

Dimov, V., Ivanoska, N., Manolova, N., Bankova, V., Nikolav, N., Popov, S. (1991). Immunomodulatory action of propolis. Influence on antiinfectious protection and macrophage function. Apidologie (Celle), 22(2), 155-162. https://hal.archives-ouvertes.fr/hal00890904/document

Drago, L., Mombelli, B., De Vecchi, E., Fassina, M.C., Tocalli, L., Gismondo, M.R. (2000). In-vitro antimicrobial activity of propolis dry extract. Journal of Chemotherapy, 12, 390-395. http://dx.doi.org/10.1179/ joc.2000.12.5.390
El-Neney, B.A. \& Awadien, N.B. (2014). The use of propolis as a source of natural additives to improve the productive performance and immune system of chickens local.1- effect on laying hen performance. 7th International Poultry Conference Proceedings, organized by Animal Production Research Institute (APRI), Ain Sukhna, Egypt. pp, 58-78.

Eroglu, N., Senem, A., Mustafa, Y., Baris, A., Sibel, S. (2016). Amino acid and vitamin content of propolis collected by native caucasican honeybees. Journal of Apicultural Science, 602), 101-109. https://doi. org/10.1515/jas-2016-0021

Eyng, C., Murakami, A.E. \& Pedroso, R.B. (2013). Crude propolis as an immunostimulating agent in broiler feed during the starter phase. Semina: Ciências Agrárias, Londrina, 34(5), 2511-2522. http://dx.doi. org/10.5433/1679-0359.2013v34n5p2511

Eyng, C., Murakami, A.E., Santos, T.C., Silveira, T.G.V., Pedroso, R.B., Lourenco, D.A.L. (2015). Immune responses in broiler chicks fed propolis extraction residue-supplemented diets. Asian-Australasian Journal of Animal Science, 28(1), 135-142. https:// doi.org/10.5713/ajas.14.0066

Freitas, J.A., Vanat, N., Pinheiro, J.W., Balarin, M.R.S., Sforcin, J.M., Venancio, E.J. (2011). The Effects of propolis on antibody production by laying hens. Poultry Science, 90, 1227-1233. https://doi.org/10.3382/ ps.2010-01315

Galal, A., Abd El-Motaal, A.M., Ahmed, A.M.H., Zaki, T.G. (2008). Productive performance and immune response of laying hens as affected by dietary propolis supplementation. International Journal of Poultry Science, 73), 272-278. http://scialert.net/qredirect. php?doi=ijps.2008.272.278\&linkid=pdf

Gómez-Caravaca, A., Gómez-Romero, M., ArráezRomán, D., Segura-Carretero, A., FernándezGutiérrez, A. (2006). Advances in the analysis of phenolic compounds in products derived from bees. Journal of Pharmaceutical and Biomedical Analysis, 47, 1220-1234. https://doi.org/10.1016/j. jpba.2006.03.002 
Haščik, P., Garlik, J., Elimam, I.O.E., Kňazovicka, V., Bobko, M., Kačaniova, M. (2014). Influence of propolis extract in Hubbard JV chickens nutrition on oxidative stability of meat. Acta Fytotechnica et Zootech, 172), 47-51. DOl: 10.15414/afz.2014.17.02.47-51

Haščík, P., Trembecká, L., Bobko, M., Kačániová, M., Čuboň, J., Kunová, S., Bučk, O. (2016). Effect of diet supplemented with propolis extract and probiotic additives on performance, carcass characteristics and meat composition of broiler chickens. Potravinarstvo, 101), 223-231. D0l: 10.5219/581

Hassan, M.G. \& Abdulla, T.A.(2011). The effect of propolis feed supplementation on hygiene and performance of broiler chickens. Iraqi Journal of Veterinary Science, 25(2), 77-82. http://www.vetmedmosul.org/ijvs

Havsteen, B.H. (2002). The biochemistry and medical significance of the flavonoids. Pharmacology \& Therapeutics, 96(2-3), 67-202. https://doi. org/10.1016/S0163-7258(02)00298-X

Hegazi, A.G., El-Miniawy, H.F. \& El-Miniawy, F.A. (1995). Effect of some honeybee products on immune response of chicken infected with Virulent NDV. Egyptian Journal of Immunology, Z(2), 79-86.

Hegazi, A., Abdou, A.M. \& Allah, F.A. (2012). Egyptian propolis 9- Its effect on chicken productivity and immune response against Newcastle disease vaccine. British Journal of Poultry Science, 7(3), 25-30. DOl: 10.5829/idosi.bjps.2012.1.3.8147

Hosnuter, M., Gurel, A., Babuccu, O., Armutcu, F., Kargi, E., Isikdemir, A. (2004). The effect of CAPE on lipid peroxidation and nitric oxide levels in the plasma of rats following thermal injury. Burns, 30, 121-125.

Hosseini, S.M., Vakili Azghandi, M., Ahani, S., Nourmohammadi, R. (2016). Effect of bee pollen and propolis (bee glue) on growth performance and biomarkers of heat stress in broiler chickens reared under high ambient temperature. Journal of Animal and Feed Sciences, 25(1), 45-51. file:///C:/Users/sohail/Downloads/6_hosseini.pdf
Huang, W.J., Huang, C.H., Wu, C.L., Lin, J.K., Chen, Y.W., Lin, C.L., Chuang, S.E., Huang, C.Y., Chen, C.N. (2007). Propolin G, a prenylflavanone, isolated from Taiwanese propolis, induces caspase-dependent apoptosis in brain cancer cells. Journal of Agricultural and Food Chemistry, 55(18), 7366-76. DOl: 10.1021/ jf0710579

Huang, S., Cui-Ping, Z., Kai, W., George, Q.L., Fu-Liang, H. (2014). Recent advances in the chemical composition of propolis. Molecules. 19, 19610-19632. DOl: 10.3390/molecules191219610

Kačániová, M., Haščík, P., Arpášová, H., Pavelková, A., Petrová, J., Hleba, L., Pochop, J., Rovná, K. (2013). Enterococcus genus identification isolated from gastrointestinal tract of chickens after bees products application using MALDI TOF MS Biotyper. Animal Science and Biotechnology, 46, 114-118. file:///C:/ Users/sohail/Downloads/172-1403-1-PB\%20(1).pdf

Kačániová, M., Rovná, K., Arpášová, H., Cuboň, J., Hleba, L., Pochop, J., Kunová, S., Haščík, P. (2012). In vitro and in vivo antimicrobial activity of propolis on the microbiota from gastrointestinal tract of chickens. Journal of Environmental Science and Health Part A ToxiclHazardous Substances \& Environmental Engineering, 4711), 1665-1671. DOl: 10.1080/10934529.2012.687248

Kleczek, K., Majewska, K., Makowski, W., Michalik, D. (2012). The effect of diet supplementation with propolis and bee pollen on the physicochemical properties and strength of tibial bones in broiler chickens. Archiv Tierzucht, 55, 97-103. http://www. archivtierzucht.de/pdf/2012/at12p097.pdf

Kleczek, K., Wilkiewicz-Wawro, E., Wawro, K., Makowski, W., Murawska, D., Wawro, M. (2014). The effect of dietary propolis supplementation on the growth performance of broiler chickens. Polish Journal of Natural Sciences, 29(2), 105-117. http://www.uwm. edu.pl/polish-journal/sites/default/files/issues/articles/kleczek_et_al._2014.pdf

Kosalec, I., Bakmaz, M., Pepeljnjak, S., \& Vladimir-Knezevic, S. (2004). Quantitative analysis of the flavonoids in raw propolis from northern Croatia. Acta 
Pharmacology, 54, 65-72. file:///C:/Users/sohail/ Downloads/6504.pdf

Kumar, S. \& Pandey, A.K. (2013). Chemistry and Biological Activities of Flavonoids: An Overview. The Scientific World Journal, 2013. Article ID: 162750. http://dx.doi.org/10.1155/2013/162750

Kumazawa, S., Hamasaka, T. \& Nakayama, T. (2004). Antioxidant activity of propolis of various geographic origins. Food Chemistry, 84(3), 329-339. https:/l doi.org/10.1016/S0308-8146(03)00216-4

Kurek-Górecka, A., Rzepecka-Stojko, A., Górecki, M., Stojko, J., Sosada, M., Swierczek-Zieba, G. (2014). Structure and antioxidant activity of polyphenols derived from propolis. Molecules, 1911), 78-101. D0l: 10.3390/molecules19010078

Lan, Y., Verstegen, M.W.A., Tamminga, S. \& Williams, B.A. (2005). The role of the commensal gut microbial community in broiler chickens. World's Poultry Science Journal, 67(1), 95-104. DOl: https://doi. org/10.1079/WPS200445

Li, Z. \& Zhang, Z. (2002). Effects of ration supplemented with propolis on live weight gain of broilers. China Poultry, 24,22.

Lotfy, M. (2006). Biological activity of bee propolis in health and disease. Asian Pacific Journal of Cancer Prevention, 71), 22-31. http://journal.waocp.org/ article_24421_e27f12cfb64e899d4a0ee2f315f985bf.pdf

Lu, J., Idris, U., Harmon, B., Hofacre, C., Maurer, J.J, Lee, M.D. (2003). Diversity and succession of the intestinal bacterial community of the maturing broiler chicken. Applied and Environmental Microbiology, 69(11), 6816-6824. DOl: 10.1128/AEM.69.11.68166824.2003

Mahmoud, M.A.M., Abdel-Mohsein, H.S. \& Mahmoud, U.T. (2014). Effect of Chinese propolis supplementation on Ross broiler chicks: microbial population in fecal matter and litter. Journal of Advanced Veterinary Research, 4(2), 77-84. http://advetresearch.com/index.php/AVR/article/view/76/74
Mahmoud, U.T., Abdel-Rahman, M.A. \& Darwish, M.H.A. (2013). The effect of Chinese propolis supplementation on Ross broiler performance and carcass characteristics. Journal of Advanced Veterinary Research, 3(4), 154-160. http://www.advetresearch. com/index.php/AVR/article/view/136/136

Mahmoud, M.A.M., Abdel-Rahman, M.A. \& Farghali, M.R.F. (2015). Antioxidant properties of Chinese propolis in Ross broilers exposed to heat stress in Egypt. Open Journal of Veterinary Medicine, 5, 197209. http://dx.doi.org/10.4236/ojvm.2015.59027

Marieke, M., Blitterswijk, H., Leven, L., Kerkvliet, J., Waerd, J. (2005). Bee products (properties, processing and marketing). Agrodok 42, NECTAR, Netherlands Expertise Centre for (sub) Tropical Apicultural Resources, pp, 33-35.

Martinez-Tome, M., Jiménez, A.M., Ruggieri, S., Frega, N., Strabbioli, R., Murcia, M.A. (2001). Antioxidant properties of Mediterranean spices compared with common food additives. Journal of Food Protection, 64(9), 1412-1419. http://jfoodprotection.org/doi/ pdf/10.4315/0362-028X-64.9.1412

Matsui, T., Ebuchi, S., Fujise, T., Abesundara, K.., Doi, S., Yamada, H., Matsumoto, K. (2004). Strong antihyperglycemic effects of water-soluble fraction of Brazilian propolis and its bioactive constituent, 3,4,5-tri-0-caffeoylquinic acid. Biological and Pharmaceutical Bulletin, 2711), 1797-1803.https://www. jstage.jst.go.jp/article/bpb/27/11/27_11_1797/_pdf

Miguel, M.G. \& Antunes, M.D. (2011). Is propolis safe as an alternative medicine? Journal of Pharmacy and Bioallied Sciences, 3(4), 479-495. DOl: 10.4103/09757406.90101

Mishra, A., Kumar, S. \& Pandey, A.K. (2013). Scientific validation of the medicinal efficacy of Tinospora cordifolia. The Scientific World Journal, Article ID: 292934. http://dx.doi.org/10.1155/2013/292934

Moreira, T.F. (1986). Chemical composition of propolis: Vitamins and amino acids. Revista Brasileira de Farmacognosia, 7(1), 12-19. http://dx.doi.org/10.1590/ S0102-95X1986000100003 
Nakajima, Y., Shimazawa, M., Mishima, S. \& Нага, H. (2007). Water extract of propolis and its main constituents, caffeoylquinic acid derivatives, exert neuroprotective effects via antioxidant actions. Life Sciences, 80(4), 370-377. DOl: 10.1016/j. Ifs.2006.09.017

Nimse, S.B. \& Pal, D. (2015). Free radicals, natural antioxidants, and their reaction mechanisms. Royal Society of Chemistry Advances, 5, 27986-28006. DOl: 10.1039/C4RA13315C

Ozkok, D., Iscan, K.M. \& Ilici, S. (2013). Effects of dietary propolis supplementation on performance and egg quality in laying hens. Journal of Animal and Veterinary Advances, 12(2), 269-275. DOl: 10.3923/ javaa.2013.269.275

Orsi, R.O., Funari, S.R.C., Soares, A.M.V.C., Calvi, S.A., Oliveira, S.L., Sforcin, J.M., Bankova, V. (2000). Immunomodulatory action of propolis on macrophage activation. Journal of Venomous Animals and Toxins Including Tropical Diseases, 6, 205-219.

Park, Y.K., Alencar, S.M. \& Aguiar, C.L. (2002). Botanical origin and chemical composition of Brazilian propolis. Journal of Agricultural and Food Chemistry, 50(9), 2502-2506. DOl: 10.1021/jf011432b

Park, J.H., Lee, J.K., Kim, H.S., Chung, S.T., Eom, J.H., Kim, K.A.,... Oh, S.U. (2004). Immunomodulatory effect of caffeic acid phenethyl ester in Balb/c mice. International Immunopharmacology, 4(3), 429-436. DOl: 10.1016/j.intimp.2004.01.013

Pavilonis, A., Baranauskas, A., Puidokaite, L., Mazeliene, Z., Savickas, A., Radziūnas, R. (2008). Antimicrobial activity of soft and purified propolis extracts. Medicina (Kaunas, Lithuania), 44(12), 977-983. PMID:19142056

Peric, l., Zikie, D. \& Lukie, M. (2009). Application of alternative growth promoters in broiler production. Biotechnology in Animal Husbandry, 25(5-6), 387-397. http://www.doiserbia.nb.rs/img/doi/14509156/2009/1450-91560906387P.pdf

Popova, M.P., Graikou, K., Chinou, I. \& Bankova, V.S.
(2010). GC-MS profiling of diterpene compounds in Mediterranean propolis from Greece. Journal of Agricultural and Food Chemistry, 58(5), 3167-3176. DOl: $10.1021 / j f 903841 \mathrm{k}$

Popova, M., Trusheva, B., Cutajar, S., Antonova, D., Mifsud, D., Farrugia, C., Bankova V. (2012). Identification of the plant origin of the botanical biomarkers of Mediterranean type propolis. Natural Product Communications, 75), 569-570.

Roodsari, M.H., Mehdizadeh, M., Kasmani, F.B., Lotfelahian, H., Mosavi, F., Abolghasemi, A.H. (2004). Effects of oil-extracted propolis on the performance of broiler chicks. Agricultural Science and Technology, 18, 57-65.

Salatino, A., Erica, W.T., Giuseppina, N. \& Dejair, M. (2005). Origin and chemical variation of Brazilian propolis. Evidenced-Base Compliment and Alternative Medicine, 2(1): 33-38. DOl: 10.1093/ecam/ neh060

Sathiavelu, J., Senapathy, G.J., Devara, R., \& Namasivayam, N. (2009). Hepatoprotective effect on chrysin on prooxidant-antioxidant status during ethanol-induced toxicity in female albino rats. Journal of Pharmacy and Pharmacology, 67(6), 809-817. DOl: 10.1211/jpp.61.06.0015

Scheller, S., Dworniczak, S., Waldemar-Klimmek, K., Rajca, M., Tomczyk, A., Shani, J. (1999). Synergism between ethanolic extract of propolis and antituberculosis drugs on growth of mycobacteria. Zeitschrift für Naturforschung, 54(7-8), 549-553. PMID:10488563

Schnitzler, P., Neuner, A., Nolkemper, S., Zundel, C., Nowack, H., Sehsch, K.H., Reichling, J. (2010). Antiviral activity and mode of action of propolis extracts and selected compounds. Phytotherapy Research, 24(1), S20-S28. DOI: 10.1002/ptr.2868

Simone-Finstrom, M. \& Spivak, M. (2010). Propolis and bee health: the natural history and significance of resin use by honey bees. Apidologie, 47(3), 295311. DOl: 10.1051/apido/2010016 
Seven, P.T. (2008). The Effects of dietary Turkish propolis and vitamin C on performance, digestibility, egg production and egg quality in laying hens under different environmental temperatures. Asian-Australasian Journal of Animal Sciences, 27(8), 1164 -1170. DOl: https://doi.org/10.5713/ ajas.2008.70605

Seven, P.T. \& Seven, I. (2008). Effect of dietary Turkish propolis as alternative to antibiotic on performance and digestibility in broilers exposed to heat stress. Journal of Applied Animal Research, 34(2), 193-196. http://dx.doi.org/10.1080/09712119.2008 9706970

Seven, T.P, Seven, I., Yilmaz, M. \& Simsek, U.G. (2008). The effects of Turkish propolis on growth and carcass characteristics in broilers under heat stress. Animal Feed Science and Technology, 146(1-2), 137-148. https://doi.org/10.1016/j.anifeedsci.2007.11.003

Seven, P.T., Yilmaz, S., Seven, I., Cerci, I.H., Azman, A., Yilmaz, M. (2009). Effects of propolis on selected blood indicators and antioxidant enzyme activities in broilers under heat stress. Acta Veterinaria Brno, 78(1), 75-83. https://doi.org/10.2754/ avb200978010075

Seven, I., Aksu, T. \& Tatli, S.P. (2010). The effects of propolis on biochemical parameters and activity of antioxidant enzymes in broiler exposed to lead induced oxidative stress. Asian-Australasian Journal of Animal Sciences, 23(11), 1482-1489. DOl: https:// doi.org/10.5713/ajas.2010.10009

Seven, I., Tatli, S.P. \& Silici, S. (2011). Effects of dietary Turkish propolis as alternative to antibiotic on growth and laying performances, nutrient digestibility and egg quality in laying hens under heat stress. Revue de Médecine Vétérinaire, 162(4), 186-191. http:// www.revmedvet.com/2011/RMV162_186_191.pdf

Seven, I., Aksu, T. \& Tatli, S.P. (2012a). The effects of propolis and vitamin c supplemented feed on performance, nutrient utilization and carcass characteristics in broilers exposed to lead. Livestock Science, 148(1-2), 10-15. https://doi.org/10.1016/j. livsci.2012.05.001
Seven, P.T., Yilmaz, S., Seven, I. \& Tuna, K.G. (2012b). The Effects of Propolis in Animals Exposed Oxidative Stress. In: Lushchak, V.l., Ed., Oxidative StressEnvironmental Induction and Dietary Antioxidants, Chap. 13, InTech Book, Rijeka, 267-288. http://cdn. intechopen.com/pdfs/36268/InTech-The_effects_ of_propolis_in_animals_exposed_oxidative_stress. pdf

Sforcin, J.M. (2007). Propolis and the immune system: a review. Journal of Ethnopharmacology, 113(1), 1-14. DOl: 10.1016/j.jep.2007.05.012

Shaddel-Tili, A., Eshratkhah, B., Kouzehgari, H. \& Ghasemi-Sadabadi, M. (2016). The effect of different levels of propolis in diets on performance, gastrointestinal morphology and some blood parameters in broiler chickens. Bulgarian Journal of Veterinary Medicine, DOl: 10.15547/bjvm.986

Shalmany, S.K. \& Shivazad, M. (2006). The effect of diet propolis supplementation on Ross broiler chicks performance. International Journal of Poultry Science, 5(1), 84-88. http://scialert.net/qredirect.php?d oi=ijps.2006.84.88\&linkid=pdf

Shihab, I.M., \& Ali, B.H. (2012). Effect of propolis in diet supplementation on the immune response against Newcastle disease and hematological picture in broiler chicks. Al-Anbar Journal of Veterinary Sciences, 5(2), 40-46. http://iasj.net/ iasj?func=fulltext\&ald=73842

Silici, S. \& Kutluca, S. (2005). Chemical composition and antibacterial activity of propolis collected by three different races of honeybees in the same region. Journal of Ethnopharmacology, 99(1), 69-73. DOl: 10.1016/j.jep.2005.01.046

Szliszka, E., Kucharska, A.Z., Sokol-Letowska, A., Mertas, A., Czuba, Z.P., Krol, W. (2013). Chemical composition and anti-inflammatory effect of ethanolic extract of Brazilian green propolis on activated 1774A.1 Macrophages. Evidence-Based Complement Alternative Medicine, Article ID 976415. http:// dx.doi.org/10.1155/2013/976415

Taheri, H.R., Rahmani, H.R. \& Pourreza, J. (2005). Hu- 
moral immunity of broilers is affected by oil extracted propolis (OEP) in the diet. International Journal of Poultry Science, 4(6), 414-417. http://scialert.net/ qredirect.php?doi=ijps.2005.414.417\&linkid=pdf

Tayeb, I.T. \& Sulaiman, B.F. (2014). Effect of propolis supplementation on productive performance in local quail. Iranian Journal of Applied Animal Science, 4(3), 621-627. http://www.sid.ir/en/VEWSSID/__ pdf/1034220140326.pdf

Tekeli, A., Kutlu, H.R., Celik, L. \& Doran, F. (2010). Determination of the effects of $Z$. officinale and propolis extracts on intestinal microbiology and histological characteristics in broilers. International Journal of Poultry Science, 9(9), 898-906. http://scialert.net/ qredirect.php?doi=ijps.2010.898.906\&linkid=pdf

Tekeli, A., Kutlu, H.R. \& Çelik, L. (2011). Effects of Z. officinale and propolis extracts on the performance carcass and some blood parameters of broiler chicks. Current Research Poultry Science, 7(1): 12-23. http:/l scialert.net/qredirect.php?doi=crpsaj.2011.12.23\&lin $\mathrm{kid}=p d f$

Trusheva, B., Popova, M., Bankova, V., Simova, S., Marcucci, M.C., Miorin, P.L., Iva, T. (2006). Bioactive constituents of Brazilian red propolis. Evidence-Based Complementary and A/ternative Medicine, 3(2), 249254. DOl: 10.1093/ecam/nel006

Vynograd, N., Vynograd, I. \& Sosnowski, Z. (2000). A comparative multicentre study of the efficacy of propolis, acyclovir and placebo in the treatment of genital herpes (HSV). Phytomedicine, 71), 1-6. DOl: 10.1016/S0944-7113(00)80014-8

Wagh, V.D. (2013). Propolis: A wonder bees product and its pharmacological potentials. Advances in Pharmacological Sciences, Article ID: 308249. http:// doi.org/10.1155/2013/308249

Wang, D., Li, X., Xu, L., Hu, Y., Zhang, B., Liu, J. (2006). Immunologic synergism with IL-2 and effects of $\mathrm{CCH}$ Mls on mRNA expression of IL-2 and IFN- $\gamma$ in chicken peripheral T Iymphocyte. Vaccine, 24(49-50), 71097114. https://doi.org/10.1016/j.vaccine.2006.07.005
Yamauchi, R., Kato, K., Oida, S., Kanaeda, J., Ueno, Y. (1992). Benzyl caffeate, an antioxidative compound isolated from propolis. Bioscience, Biotechnology and Biochemistry, 56(8), 1321-1322. http://dx.doi. org/10.1271/bbb.56.1321

Zafarnejad, K., Nazar, A. \& Mostafa, R. (2017). Effect of bee glue on growth performance and immune response of broiler chickens. Journal of Applied Animal Research, 459(1), 280-284. http://dx.doi.org/10.108 0/09712119.2016.1174130

Zeng, Z., Liu, S., Pan, K., Wu, H., Tang, K. (2004). Effects of pollen and propolis on productive and immune performance in meat fowl. Scientia Agricultura Sinica, 375), 751-755. http://www.chinaagrisci. com/EN/volumn/volumn_1939.shtml

Zeweil, H.S., Zahran, S.M., Abd El-Rahman, M.H.A., Dosoky, W.M., Abu Hafsa, S.H., Moktar, A.A. (2016). Effect of using bee propolis as natural supplement on productive and physiological performance of Japanese quail. Egyptian Poultry Science Journal, 36(1), 161-175. http://www.epsaegypt.com/wp-content/ uploads/2016/03/1612_final_2016.pdf

Zhi-jiang, Z, San-Feng, L., Ke, P., Hong-Xiang, W. Kai-jie, T. (2004). Effects of pollen and propolis on productive and immune performance in meat fowl. Scientia Agriculura Sinica. 37: 751-755. http://www. chinaagrisci.com/EN/article/downloadArticleFile. do?attachType=PDF\&id=14828

Ziaran, H.R., Rahmani, H.R. \& Pourreza, J. (2005). Effect of dietary oil extract of propolis on immune response and broiler performance. Pakistan Journal of Biological Sciences, 8(10), 1485-1490. http://scialert. net/qredirect.php?doi=pjbs.2005.1485.1490\&linkid= pdf 